\title{
Pesticides in Surface Waters of the Hudson River Basin - Mohawk River Subbasin
}
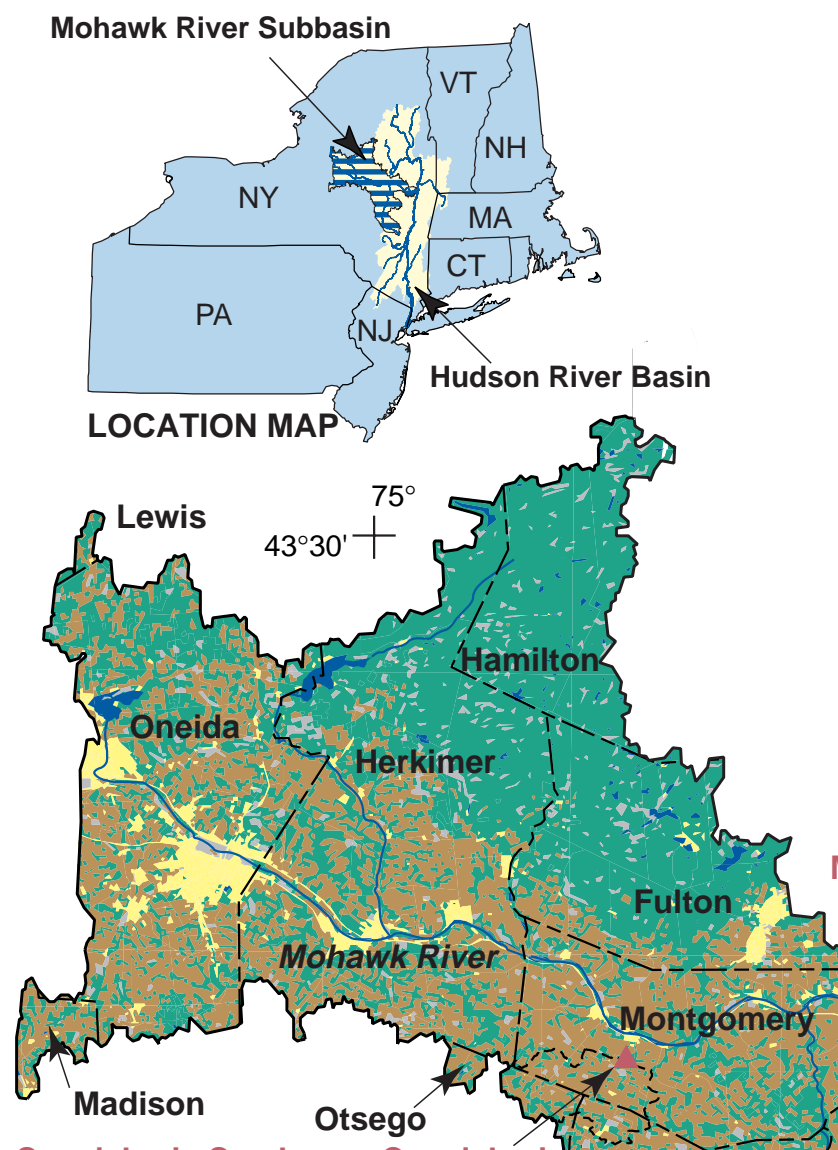

Canajoharie Creek near Canajoharie

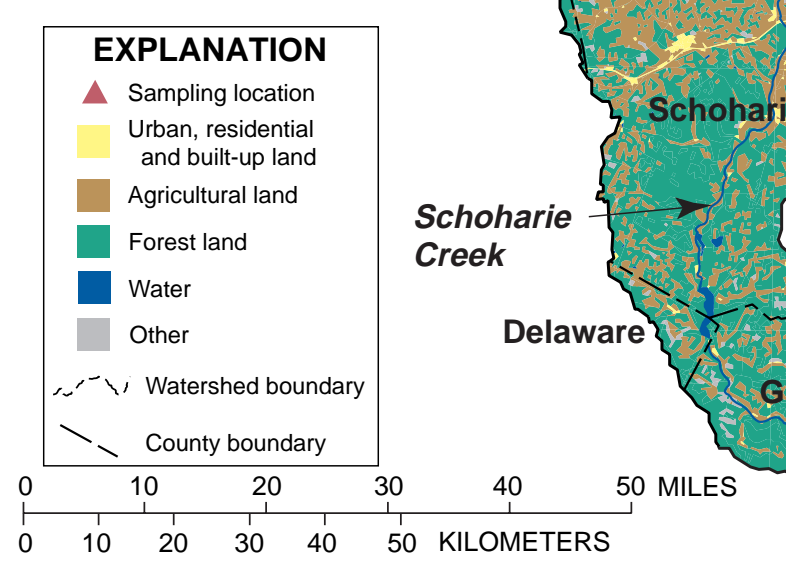

Base from U.S. Geological Survey digital data 1:2,000,000, 1972

Figure 1: Land use and sampling locations in Mohawk River subbasin, New York

\section{Introduction and Basin Description}

The National Water Quality Assessment (NAWQA) program is designed to describe the status and trends in the water quality of large representative parts of the Nation's surface-water and ground-water resources and to provide a scientific understanding of the major natural and human factors that affect the quality of these resources. The Hudson River Basin, one of 60 NAWQA project areas, encompasses 13,400 $\mathrm{mi}^{2}$ (square miles) in New York and adjacent states, and the Mohawk River is the largest tributary to the Hudson River (fig. 1). The Mohawk subbasin encompasses $3,519 \mathrm{mi}^{2}$ and represents about 25 percent of the Hudson River Basin. About 55 percent of the Mohawk subbasin is forested land, 33 percent is agricultural land, 7 percent is urban/residential land, and 5 percent is wetland, water, or other land cover (fig. 1). The diverse land use within this large subbasin makes it a probable major contributor of various pesticides to the Hudson River.

Water samples collected from streams in the Mohawk River subbasin were analyzed for a broad suite of pesticides, which included both herbicides and insecticides. Herbicides are used to control weeds in agricultural fields as well as lawns, commercial land, and other open areas
Mohawk River at Cohoes

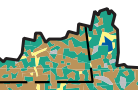

s.

sćnenedtady

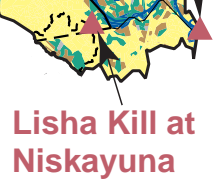

$74^{\circ}$ in urban and residential settings; insecticides are used to control insects in agricultural and urban settings. Because pesticides can be transported from application areas to surface waters, stream and river monitoring for pesticides in the Hudson River Basin is needed to insure both a safe drinking water supply and the ecological health of streams. This fact sheet summarizes results of a study of pesticides in streams in the Mohawk River subbasin.

\section{Pesticide Sampling}

Three surface water sites were sampled monthly or weekly for 47 pesticides (for a complete list of pesticide analytes, refer to Firda and others, 1994) from March 1994 through September 1995 to determine the variability of pesticide concentrations with respect to season, streamflow conditions, and land use. These sites included (1) Canajoharie Creek, which drains a $60 \mathrm{mi}^{2}$ watershed, 66 percent of which is agricultural land, (2) Lisha Kill, which drains a $15 \mathrm{mi}^{2}$ watershed, 56 percent of which is urban land, and (3) the Mohawk River at Cohoes which represents the outlet of the Mohawk River which drains a combination of urban, forested, and agricultural land. Canajoharie Creek and Lisha Kill watersheds are nested within the Mohawk River subbasin and shown in figure 1 . 


\section{Results of Sample Analyses}

Eighteen pesticides were detected among the three sites (table 1), including 12 herbicides, two herbicide-degradation products (metabolites), and four insecticides. Of the 108 samples collected at the three sites, only two contained any pesticide at a concentration that exceeded the maximum contaminant level (MCL) or health advisory (HA) level as established by the U.S. Environmental Protection Agency (USEPA, 1996), and both samples were from Canajoharie Creek. One sample exceeded the MCL for the herbicide atrazine ${ }^{1}$ with a concentration of $4.3 \mu \mathrm{g} / \mathrm{L}$ (micrograms per liter). This sample was collected after a runoff-

${ }^{1}$ Use of trade, product, or firm names is for descriptive purposes only and does not imply endorsement by the U.S. Government. producing storm in July 1994 and represents the largest instantaneous discharge associated with any sample collected at Canajoharie Creek during the growing seasons of 1994 and 1995. The other sample, collected after a smaller storm in June 1995, had a cyanazine concentration of $2.1 \mu \mathrm{g} / \mathrm{L}$, which exceeds the HA standard for cyanazine.

The highest concentrations of all but three pesticides detected at the three sites (alachlor - seven detections, 2,6-diethylanaline three detections, and tebuthiuron - one detection) were in samples from either Canajoharie Creek or Lisha Kill (table 1). These three pesticides were in 8 separate samples (six from the Mohawk River site). Tebuthiuron and 2,6-diethylanaline were detected only at the Mohawk River site, and all three 2,6-diethylanaline detections were in association with alachlor in samples collected on June 21, 29 and July 6, 1994.

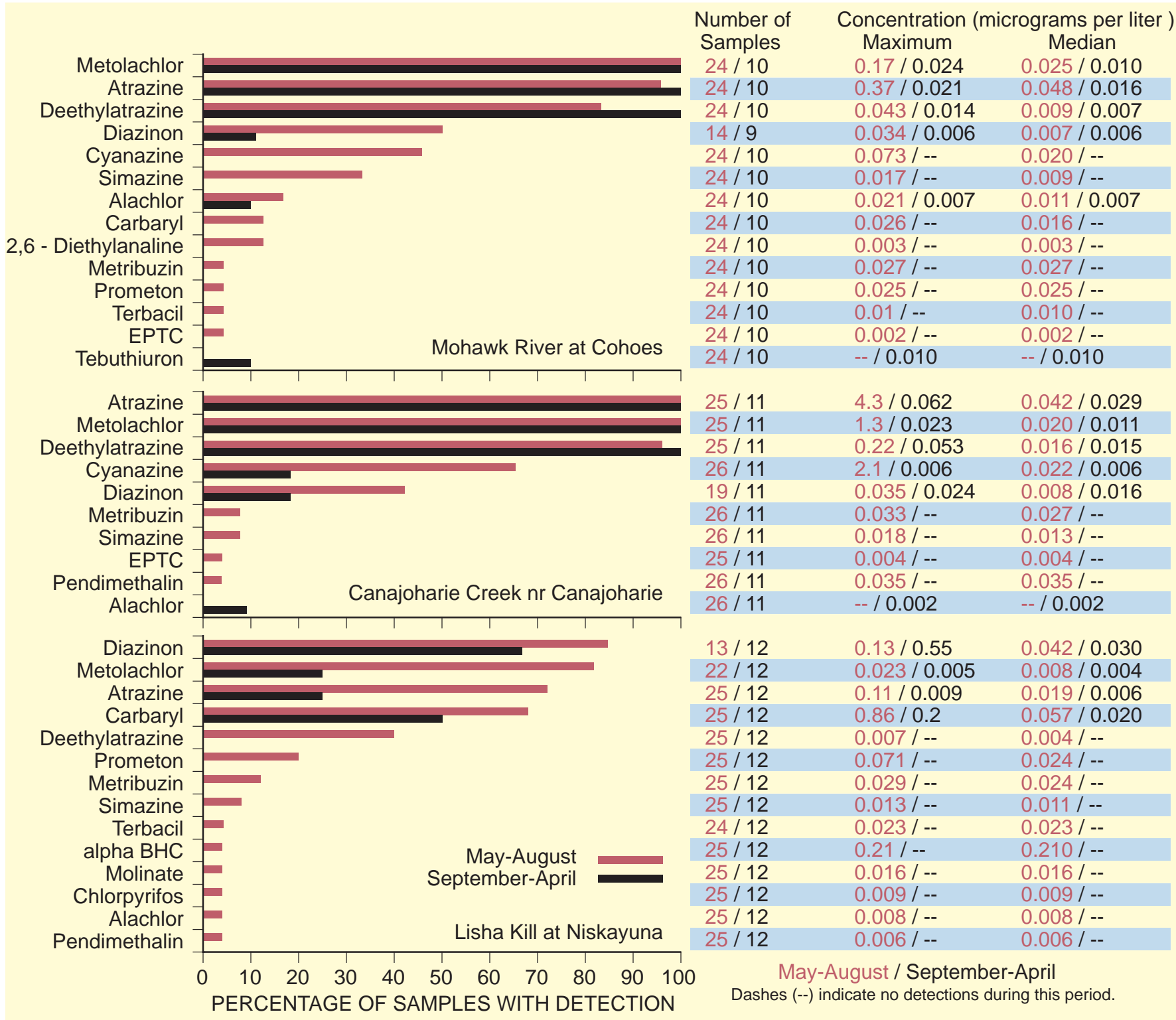

Figure 2: Percent detection, maximum and median (of samples with detection) concentrations of detected pesticides at sampling sites (site locations shown in fig. 1) 
The Mohawk River drains a large watershed, and receives water from many tributaries draining forested, urban, and agricultural lands. The lower concentrations of pesticides found at the Cohoes site than at the Canajoharie Creek and Lisha Kill sites, therefore, can be attributed to dilution.

Canajoharie Creek is adjacent to areas where agricultural chemicals are applied; therefore, the detection of agricultural pesticides, including atrazine, cyanazine, metolachlor, pendimethalin, metribuzin, and simazine in relatively high concentrations was not surprising. Similarly, the highest concentrations of all four insecticides found were in samples from the Lisha Kill, as this watershed contains many urban/ residential areas.

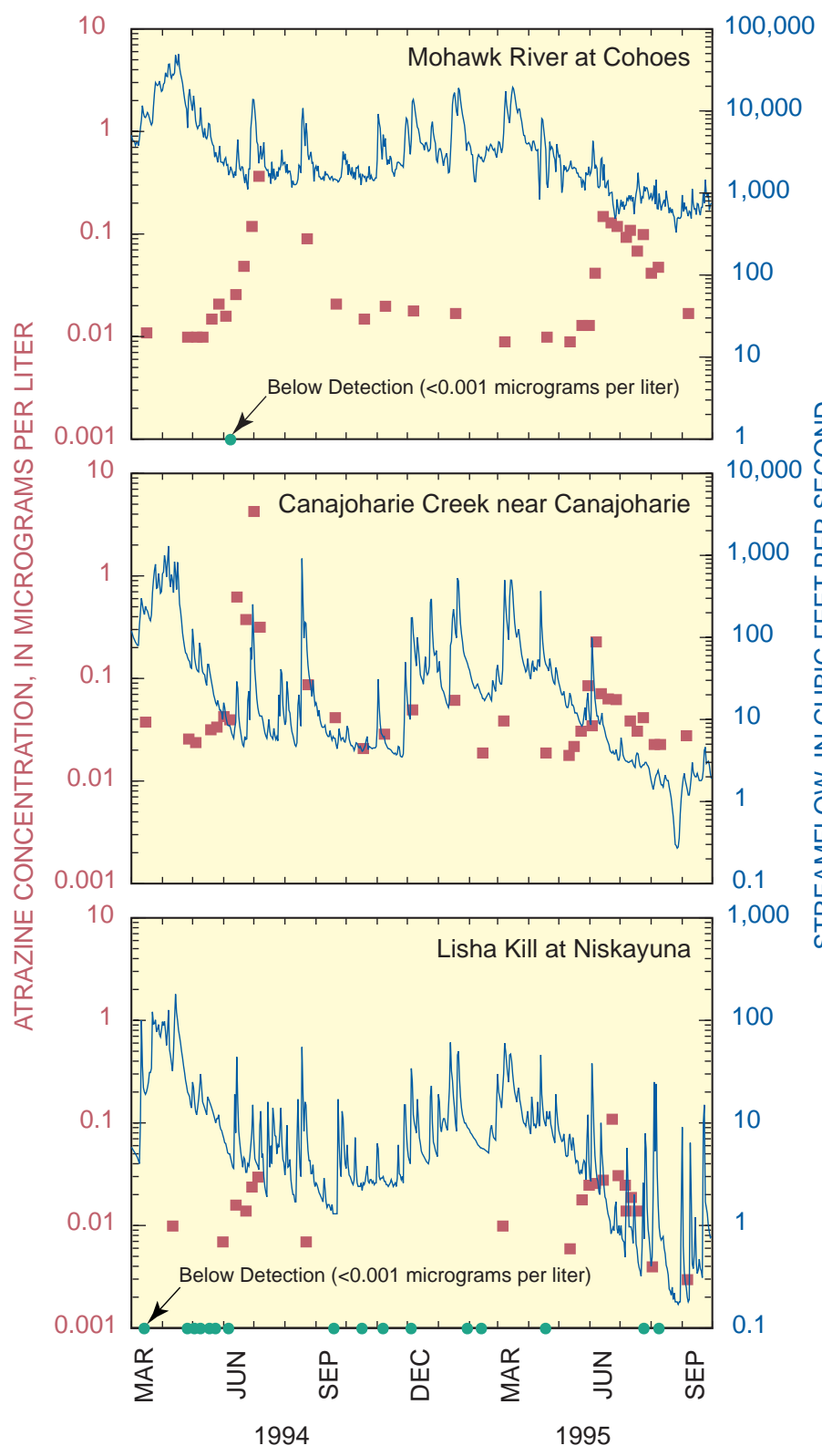

Figure 3: Annual atrazine concentrations at each site (site locations shown in fig. 1)
Table 1. Pesticides detected

\begin{tabular}{|c|c|c|c|c|}
\hline \multirow[b]{2}{*}{$\begin{array}{l}\text { Pesticides } \\
\text { detected }\end{array}$} & \multirow[b]{2}{*}{ Use $^{1}$} & \multicolumn{3}{|c|}{$\begin{array}{c}\text { Concentration } \\
\text { (micrograms per liter) }\end{array}$} \\
\hline & & $\begin{array}{l}\text { Detection } \\
\text { Limit }\end{array}$ & $\mathrm{MCL} / \mathrm{HA}^{2}$ & $\begin{array}{l}\text { Maximum } \\
\text { detected }\end{array}$ \\
\hline Atrazine & $\mathrm{H}$ & 0.001 & 3 & 4.3 \\
\hline Cyanazine & $\mathrm{H}$ & 0.004 & 1 & 2.1 \\
\hline Metolachlor & $\mathrm{H}$ & 0.002 & 100 & 1.3 \\
\hline Carbaryl & I & 0.003 & 700 & 0.86 \\
\hline Diazinon & I & 0.002 & 0.6 & 0.55 \\
\hline Deethylatrazine & M & 0.002 & na & 0.22 \\
\hline alpha BHC & I & 0.002 & na & 0.21 \\
\hline Prometon & $\mathrm{H}$ & 0.018 & 100 & 0.071 \\
\hline Pendimethalin & $\mathrm{H}$ & 0.004 & na & 0.035 \\
\hline Metribuzin & $\mathrm{H}$ & 0.004 & 100 & 0.033 \\
\hline Terbacil & $\mathrm{H}$ & 0.007 & 90 & 0.023 \\
\hline Alachlor & $\mathrm{H}$ & 0.002 & 2 & 0.021 \\
\hline Simazine & $\mathrm{H}$ & 0.005 & 4 & 0.018 \\
\hline Molinate & $\mathrm{H}$ & 0.004 & na & 0.016 \\
\hline Tebuthiuron & $\mathrm{H}$ & 0.01 & 500 & 0.01 \\
\hline Chlorpyrifos & I & 0.004 & 20 & 0.009 \\
\hline EPTC & $\mathrm{H}$ & 0.002 & na & 0.004 \\
\hline 2,6 - Diethylanaline & M & 0.003 & na & 0.003 \\
\hline
\end{tabular}

Colors indicate the site at which the maximum concentration was found Yellow - Canajoharie Creek, Red - Lisha Kill, Blue - Mohawk River ${ }^{1} \mathrm{H}$ - herbicide, I - insecticide, $\mathrm{M}$ - metabolite,

${ }^{2} \mathrm{MCL}$ - Maximum Contaminant Level, HA - Health Advisory level

The presence and concentrations of pesticides detected at the three sites is depicted in figure 2. Metolachlor, atrazine, and deethylatrazine were nearly always detected in both the Mohawk River and Canajoharie Creek, although the maximum and median concentrations in Canajoharie Creek were typically greater than those in the Mohawk River.

Diazinon was detected most frequently in samples from Lisha Kill and was present in more than 80 percent of samples collected from May through August and in more than 60 percent of samples collected from September through April. Diazinon is applied almost exclusively in urban/residential areas; thus, the greater frequency of detection and higher concentrations of diazinon in samples from the Lisha Kill than in the Mohawk River is attributed to the larger proportion of urban/residential land in the Lisha Kill watershed. No samples from Canajoharie Creek, which drains an area that is less than 1.5 percent urban/residential, had detectable concentrations of diazinon.

The higher percentage of pesticide detections during the growing season (May through August) than in the nongrowing season (fig. 2) reflects the amount of time since pesticides were applied to fields and urban areas. Most detections during the nongrowing season were likely the result of pesticide infiltration to ground water and its subsequent discharge to streams and rivers later in the year. 


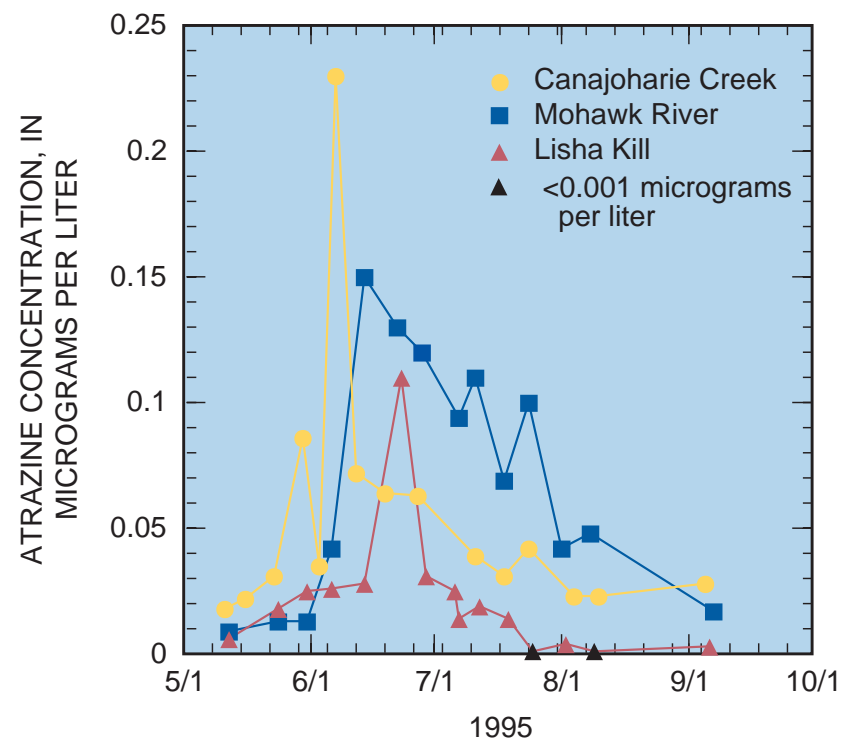

Figure 4: Atrazine concentrations at the three sites, May-September 1995 (site locations shown in fig. 1)

\section{Seasonal Atrazine Patterns}

Pesticide concentrations at Canajoharie Creek and Mohawk River sites peaked during the first major runoff-producing storms after pesticide application. In general, seasonal patterns (not necessarily concentrations) of detected pesticides at these sites mimicked those of atrazine (fig. 3). The highest atrazine concentrations were at Canajoharie Creek watershed and occurred during June and July, when they ranged from 0.04 to more than $1 \mu \mathrm{g} / \mathrm{L}$. During the remainder of the year, atrazine concentrations generally ranged from 0.02 to $0.04 \mu \mathrm{g} / \mathrm{L}$.

Atrazine concentrations in the Mohawk River at Cohoes ranged from 0.04 to $0.37 \mu \mathrm{g} / \mathrm{L}$ during the growing season and were less than $0.04 \mu \mathrm{g} / \mathrm{L}$ during the remainder of the year. The sample with the highest atrazine concentration at this site was collected in July 1994, about 1 week after the maximum atrazine concentration observed at Canajoharie Creek. The timing of maximum concentrations of metolachlor and cyanazine at this site parallel those of atrazine; the maximum concentration of deethylatrazine was observed after a stormflow in August 1994.

Atrazine concentrations at Lisha Kill were lower, and the maximum observed concentrations occurred later, than at the Mohawk River and Canajoharie Creek sites. Atrazine was detected at Lisha Kill only between March and September of 1994 and 1995, and the peak concentration observed at Lisha Kill was not associated with a runoff-producing storm. The maximum concentration of neither metolachlor nor deethylatrazine corresponded to the maximum concentration of atrazine at Lisha Kill.

Differences in the timing of observed peak concentrations of atrazine in the summer of 1995 among the three sites (fig. 4) is due to differences in the time of application and the response of streamflow to precipitation. The 1995 sample with the maximum atrazine concentration at Canajoharie Creek was collected in early June, and, as in 1994, 7 days before the maximum atrazine concentration detected in the Mohawk River at Cohoes. This delay in peak concentration is not surprising, however, because a small watershed will generally respond faster to a storm than a large basin, and this, combined with the large proportion of agricultural land in the watershed, resulted in a more rapid increase in atrazine concentration, and higher concentrations, than at the two other sites. Because the Mohawk site is downstream from Canajoharie Creek and receives runoff from several other small watersheds dominated by agricultural land, elevated concentrations in the Mohawk are sustained longer than in Canajoharie Creek. In addition, several impoundments along the Mohawk River probably slow the movement of atrazine and other herbicides toward the Cohoes site.

Because land use in the Lisha Kill watershed is predominantly urban/residential, and a much smaller proportion of the watershed is agricultural than in the Mohawk or Canajoharie watersheds, the later peak in atrazine concentration at Lisha Kill could be the result of a different usage and timing of applications.

\section{—Gary R. Wall and Patrick J. Phillips}

\section{References Cited}

USEPA, 1996, Drinking Water Regulations and Health Advisories, EPA 822-B-96-002.

Firda, G. D., Lumia, R., Murray, P. M., and Freeman, W. O., 1994, U.S. Geological Survey Water-Data Report NY-94-1.

\section{For additional information contact:}

\author{
Hudson River NAWQA Project Chief \\ U.S. Geological Survey \\ 425 Jordan Road \\ Troy, NY 12180
}

This fact sheet and related information can be found on the World Wide Web at: http://wwwdnyalb.er.usgs.gov

Additional earth science information can be obtained by accessing the USGS "Home Page" on the World Wide Web at: http://water.usgs.gov 